\title{
Spatial and temporal characterization of water and solute distribution patterns
}

\author{
Claudinei Fonseca Souza ${ }^{1}$; Marcos Vinícius Folegatti2** \\ ${ }^{1}$ UFSCar/CCA - Depto. de Recursos Naturais e Proteção Ambiental, Rod. Anhanguera, km 174 - SP 330 - \\ 13600-970 - Araras, SP - Brasil. \\ ${ }^{2}$ USP/ESALQ - Depto. de Engenharia de Biossistemas, Av. Pádua Dias, 11 - 13418-900 - Piracicaba, SP - Brasil. \\ *Corresponding author <mvfolega@esalq.usp.br>
}

\begin{abstract}
The use of drip irrigation and marginal water is growing rapidly in some areas, highlighting the need to develop sound fertigation practices that combine environmental and crop production concerns. In this study the spatial and temporal water and solute distribution patterns are characterized to underpin fertirrigation design and management systems. Time domain reflectometry (TDR) probes were used to monitor the distributions of potassium nitrate $\left(\mathrm{KNO}_{3}\right)$ and water from drippers discharging at a constant flow rate of $4 \mathrm{~L} \mathrm{~h}^{-1}$ in soil-filled containers. In the interactions between the different profiles, a gradient distribution of the solution in the soil was observed, with greater storage of solution close to the dripper, which decreased gradually as it approached the wetting front. To reduce leaching of fertigated ions, the frequent application of small amounts of solution during irrigation is recommended.
\end{abstract}

Key words: TDR, drip irrigation, wetted soil volume

\section{Caracterização espacial e temporal de padrões de distribuição da água e do soluto}

\begin{abstract}
RESUMO: O uso de irrigação por gotejamento e água de reúso está crescendo rapidamente em algumas áreas, destacando a necessidade para desenvolver práticas de fertirrigação que combinem preocupações ambientais dentro da produção vegetal. Caracterizou-se espacial e temporalmente os padrões de distribuição da água e do soluto para auxiliar o dimensionamento e manejo de sistemas de fertirrigação. O experimento foi conduzido numa caixa de solo, com monitoramento por TDR da distribuição de solução de nitrato de potássio $\left(\mathrm{KNO}_{3}\right)$, aplicada via gotejador de vazão de $4 \mathrm{~L} \mathrm{~h}^{-1}$. Observou-se distribuição em gradiente da solução no solo nas interações entre os perfis (umidade versus condutividade elétrica), sendo verificado maior armazenamento da solução próximo ao gotejador e, conseqüentemente, diminuição desta à medida que se aproxima da frente de molhamento. Sugere-se, para a redução da lixiviação dos íons fertirrigados, a aplicação de pequenos volumes de solução durante a irrigação, mas com maior freqüência.

Palavras-chave: TDR, irrigação por gotejamento, bulbo molhado
\end{abstract}

\section{Introduction}

In addition to maximizing crop production, modern fertigation practices must combine environmental sustainability and rigorous water management. These often conflicting considerations require significant changes in irrigation system design and operation (relative to systems for maximal crop production) (Souza and Matsura, 2004). Among the available irrigation methods, drip irrigation offers key advantages for meeting contemporary water and nutrient management efficiency standards, since it allows accurate control of water supplied in small quantities directly to the root zone. Frequent irrigation helps to maintain favorable water conditions (near field capacity) for root proliferation in the partially wetted soil volume.

The dimensions and extent of a wetted soil volume are determined by soil type (texture and structure), dripper discharge rate and spacing, and water application frequency (and initial soil water content early in the season) (Dasberg and Or, 1999). Unfortunately, these im- portant factors in both design and management are often overlooked, and current practices in Brazil and elsewhere are too often based on empirical information or on data gleaned indiscriminately from professional literature.

Characterization of the wetted soil volume under field conditions offer a practical means for gathering the relevant information required for system design (Keller and Bliesner, 1990). This characterization, however, tends to be time consuming and costly and, therefore, rarely performed. Alternatively, the wetted soil volume can be measured and controlled by using water content sensors such as time-domain reflectometers (TDR), which can estimate water content and electrical conductivity using a single probe within the same volume (Topp et al., 1980; Coelho and Or, 1996; Souza and Matsura, 2003). Thus, the purpose of this study was to characterize water and solute distribution patterns spatially and temporally in order to underpin the design and management of drip irrigation systems.

Sci. Agric. (Piracicaba, Braz.), v.67, n.1, p.9-15, January/February 2010 


\section{Material And Methods}

The experiment was carried out in a $100 \mathrm{~m}^{2}$ greenhouse of an experimental irrigation farm in Piracicaba, state of São Paulo, Brazil (22 ${ }^{\circ} 42^{\prime}$ 'S and $47^{\circ} 37^{\prime} \mathrm{W}, 550 \mathrm{~m}$ a.s.1.). Surface layer $(0-0.3 \mathrm{~m})$ of a soil (Typic Hapludox) was collected, dried, sieved ( $>2$ $\mathrm{mm})$ and packed in instrumented containers $(0.65 \mathrm{~m}$ in height and $1.1 \mathrm{~m}$ in diameter) by compacting layers of $0.05 \mathrm{~m}$ to reproduce field density (according to the methodology used by Vieira and Francisco (1986) and Mmolawa and Or (2000)). Table 1 lists the primary physical and chemical characteristics of the soil.

The test container was equipped with 36 3-rod TDR probes (Figures 1 and 2). The probes were measured using a Tektronix 1502C (Oregon, USA) TDR cable tester equipped with a RS 232 interface, and the waveforms thus collected were automatically analyzed using the WinTDR 6.0 software (reference). Tests showed that 12 min were needed for each reading cycle of soil water content and electrical conductivity of the 36 TDR probes. The calibration equation presented by Tommaselli \& Bacchi (2001) to convert the bulk dielectric constant $\mathrm{Ka}$ into soil water content $\mathrm{q}\left(\mathrm{m}^{3} \mathrm{~m}^{-3}\right)$ was used.

$\theta=-0.0202+0.0257 \mathrm{Ka}-0.0007 \mathrm{Ka}^{2}+1 \mathrm{E}-5 \mathrm{Ka}^{3}$

The TDR probes (rod length of $200 \mathrm{~mm}$ and $3 \mathrm{~mm}$ in diameter; rod spacing of $15 \mathrm{~mm}$ ) were built and calibrated according to methodologies described by Souza et al. (2006a and 2006b) and Rhoades et al. (1976). The following equations were used:

$\mathrm{EC}=\frac{\mathrm{EC}_{\mathrm{TDR}}-0.04}{(2.61 \theta-0.16) \theta}$

$\mathrm{C}=\left[\frac{\mathrm{EC}}{0.17}\right]^{\frac{1}{0.92}}$.

where: $\mathrm{EC}=$ Electrical conductivity, $\mathrm{dS}^{-1} ; \mathrm{EC}_{\mathrm{TDR}}=$ Bulk Electrical conductivity, $\mathrm{dS}^{-1}$; $\mathrm{C}=$ Solution concentration $\left(\mathrm{KNO}_{3}\right)$, $\mathrm{mmol} \mathrm{L}^{-1}$
The TDR probes were deployed with $0.1 \mathrm{~m}$ spacing on an axisymmetrical grid around the dripper (Figure 1A), forming a vertical and horizontal mesh, and assumed that each probe was measuring the conditions in a soil an area of $0.01 \mathrm{~m}^{2}$ (Figure 1B). Thus, the volume of solution stored in the soil was estimated, each two TDR probes being symmetrically positioned in opposite directions representing a concentric soil ring. Therefore, the average soil water content of each ring was multiplied by the respective soil volume, which allowed

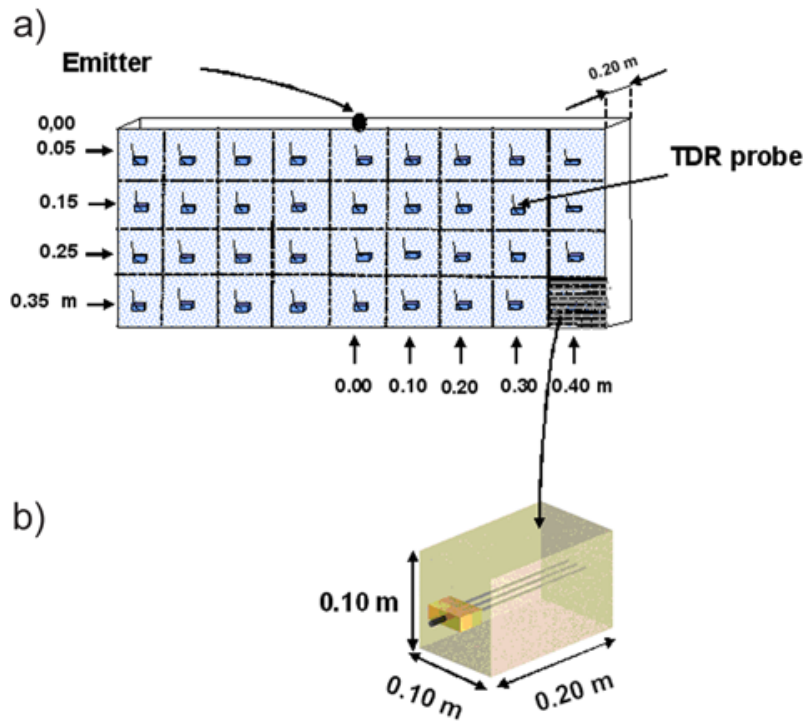

Figure 1 - a) Scheme of the experimental setup. b) Volume of soil measured by each TDR probe.

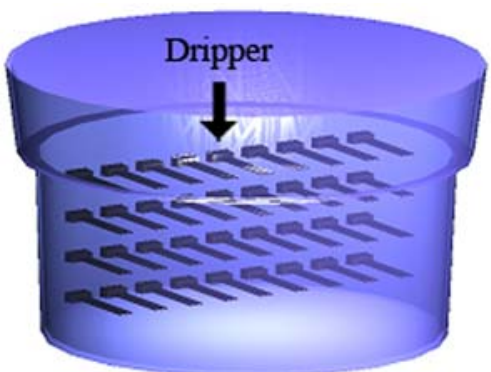

Figure 2 - Arrangement of the probes inside the container.

Table 1 - Physical and chemical characteristics of the soil.

\begin{tabular}{|c|c|c|c|c|c|c|c|c|c|c|}
\hline \multicolumn{11}{|c|}{ Physical characteristics } \\
\hline \multirow{2}{*}{ Depth } & \multirow{2}{*}{\multicolumn{2}{|c|}{ Bulk density }} & \multirow{2}{*}{\multicolumn{2}{|c|}{ Total porosity }} & & \multicolumn{3}{|c|}{ Texture } & & \multirow{2}{*}{ Ksat } \\
\hline & & & & & & Clay & Silt & Sand & & \\
\hline $\mathrm{m}$ & \multicolumn{2}{|c|}{$\mathrm{kg} \mathrm{m}^{-3}$} & \multicolumn{2}{|c|}{$\%$} & & \multicolumn{3}{|c|}{$\mathrm{g} \mathrm{kg}^{-1} \ldots$} & & $\mathrm{m} \mathrm{h}^{-1}$ \\
\hline $0-0.3$ & \multicolumn{2}{|c|}{1,428} & \multicolumn{2}{|c|}{46} & & 170 & 110 & 720 & & 0.16 \\
\hline \multicolumn{11}{|c|}{ Chemical characteristics } \\
\hline Depth & $\mathrm{pH}$ & $\mathrm{P}$ & $\mathrm{OM}$ & $\mathrm{H}+\mathrm{Al}$ & $\mathrm{K}$ & $\mathrm{Ca}$ & $\mathrm{Mg}$ & SB & CEC & BS \\
\hline $\mathrm{m}$ & & $\mu \mathrm{g} \mathrm{cm}^{-3}$ & $\mathrm{~g} \mathrm{dm}^{-3}$ & 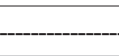 & -3 & $-\mathrm{mmc}$ & -3 & 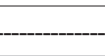 & 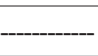 & $\%$ \\
\hline $0-0.3$ & 4.6 & 5 & 6.9 & 31 & 1.8 & 24 & 9 & 35 & 65.6 & 53 \\
\hline
\end{tabular}

$\mathrm{K}_{\text {sat }}$ - Saturated hydraulic conductivity; OM - Organic matter; SB - sum of bases; CEC - Cation exchange capacity; BS - Percent base saturation. 
obtaining the volume of partially or totally stored water (Souza and Matsura, 2004). Consequently, the wetted soil volume was observed at the $4 \mathrm{~L} \mathrm{~h}^{-1}$ flow rate, with $1 \mathrm{~L}$ solution applications at 1-h intervals. The dripper Polytif model by Plastro was used, with a constant head maintained by a Mariotte bottle system (hence the dripper discharge rate), which supplied potassium nitrate $\left(\mathrm{KNO}_{3}\right)$ as test fertilizer (see Coelho and Or [1999] and Wiens et al. [2002] for further details). The nutrient concentration in the irrigation water was $14.5 \mathrm{mmol} \mathrm{L}^{-1}$ of $\mathrm{KNO}_{3}$, resulting in an electrical conductivity of $2 \mathrm{dS} \mathrm{m}^{-1}$ (moderate risk of salinity).

The distribution and storage of solution in the soil were measured with TDR probes after each application of solution. From a single punctual probe, it was possible to estimate the water content and the concentration of solution in the soil, thus allowing monitoring the dynamics of the soil solution. Measurements were analyzed using a 3D surface mapping program which presented the ion distribution profile as a function of the water content and electrical conductivity throughout the experiment.

A central control volume was assumed inside the wetted soil volume for a comparative analysis of distribution uniformity, in order to understand the differences between the estimated individual values of moisture and concentration in the control volume, which was based on the soil volume exploited by the effective root system depth of a hypothetical crop. Thus, Christiansen's (1941) uniformity coefficients were calculated for the estimated moisture and concentrations after each application of the solution, based on equation (1), following the methodology adapted by Ould Mohamed El-Hafedh et al. (2001) and Wu and Gitlin (1983).

$$
\text { CUC }=100\left[1-\frac{\sum\left|\mathrm{X}_{\mathrm{i}}-\overline{\mathrm{X}}\right|}{\overline{\mathrm{X}} \mathrm{N}}\right]
$$

where CUC $=$ Christiansen's uniformity coefficient, \%; $X_{i}=$ estimated water content, $\mathrm{m}^{3} \mathrm{~m}^{-3}$; or estimated nutrient concentration, $\mathrm{mmol} \mathrm{L}^{-1} ; \bar{x}=$ average water content, $\mathrm{m}^{3} \mathrm{~m}^{-3}$; or nutrient concentration average, $\mathrm{mmol}$ $\mathrm{L}^{-1} ; \mathrm{N}=$ estimated point numbers.

The chosen control volume was $0.50,0.50,0.40 \mathrm{~m}$ in length, width and depth, respectively, with the dripper installed at the central point. Soil electrical conductivity was converted into the concentration of potassium nitrate in $\mathrm{mmol} \mathrm{L}^{-1}$ using the calibration equations 2 and 3. The data on distribution and storage of the solution in the soil provided basic information on the effects of the water-soil-solute relation, serving to underpin the design and management of drip fertigation systems.

\section{Results and discussion}

\section{Experimental observation}

An excellent symmetry of water flow in the vertical and horizontal directions was observed. Figure 3 shows the soil moisture profiles at the $4 \mathrm{~L} \mathrm{~h}^{-1}$ flow rate, in 12 applications of $1 \mathrm{~L}$ at 1 -h intervals. Note the faster evolution of the vertical infiltration in relation to the horizontal infiltration. A problem observed in the experiment was the premature reach of the wetting front to the bottom of the soil container, which occurred during the seventh application. This problem influenced the dimensions of wetted soil volume due to the impermeability of the soil container bottom.

\section{Saturated disc versus wetted soil surface area}

The saturated disc (the puddle remaining on the soil during the infiltration process) and the advance of the wetting front on the soil surface were measured with a millimeter ruler (Figure 4). The saturated soil disc became stable after the sixth solution application (Figure 5). Initially, the radius of the saturated disc area was $0.005 \mathrm{~m}\left(0.00008 \mathrm{~m}^{2}\right)$, reaching its apex at $0.028 \mathrm{~m}(0.0025$ $\mathrm{m}^{2}$ ).

Based on the estimated area of the wetted soil surface, a congruous expansion was observed with the evolution of the saturated radius. The horizontal radius of the wetted soil reached $0.14 \mathrm{~m}\left(0.06 \mathrm{~m}^{2}\right)$ and $0.27 \mathrm{~m}(0.23$ $\mathrm{m}^{2}$ ), respectively, after infiltration of the first and twelfth solution applications. Figure 6 also reveals a tendency for stability in this variable. The results are consistent with the reports of Bresler (1978) and Ould Mohamed El-Hafedh et al. (2001), who describe an increment in the superficial horizontal radius of the wetted soil volume in field experiments in response to the application of increasing amounts of water.

The percentage of wetted area depends on factors relating dripper spacing, discharge rate and soil physical properties. However, the ideal minimum area for dimensioning the system is not yet defined; although Keller and Bliesner (1990) state that a percentage of less than $67 \%$ for arid regions and more than 33\% for regions of complementary irrigation is reasonable. In our case, the observed percentage $(23 \%)$ did not follow the recommendation, but the total surface area of the soil container was considered for this calculation. The possibility of changing the surface area of the wetted soil through different combinations of spacing between drippers is also an important point. A smaller wetted area reduces water loss by evaporation. Economic considerations are indispensable in view of the investments in the project with increasing numbers of drippers, confirming the relevance of studying different combinations of spacing between drippers.

The results reveal a strong correlation between the surface area of wetted soil and the saturated radius of the soil under study. This correlation will be investigated in greater depth to obtain information about the horizontal formation of wetted soil volume based on field tests.

The vertical water movement was extremely marked, since the superficial wetted area stabilized after the sixth solution application. This finding alone justifies studies on the evolution of wetted soil volumes 
aimed at reducing losses through leaching, since the results can reveal a trend for probable contamination of the water table, which may give rise to eutrophication of ground and surface waters. Leaching may increase the variable costs of agricultural production through wasted electrical energy, labor, fertilizers, water, etc.

The purpose of working in a laboratory, using a control volume inside a container, was to estimate a soil volume explored by the effective root system of a hypo- thetical plantation. An analysis of this simulation revealed considerable loss of water and fertilizer in just six successive fertigations, reinforcing the argument in favor of this type of study.

Distribution and storage of the solution in the soil

Some of the parameters that could influence the movement of the solution in the soil were monitored during the experiment. The parameters measured were

Distance from the dripper ( $m$ )
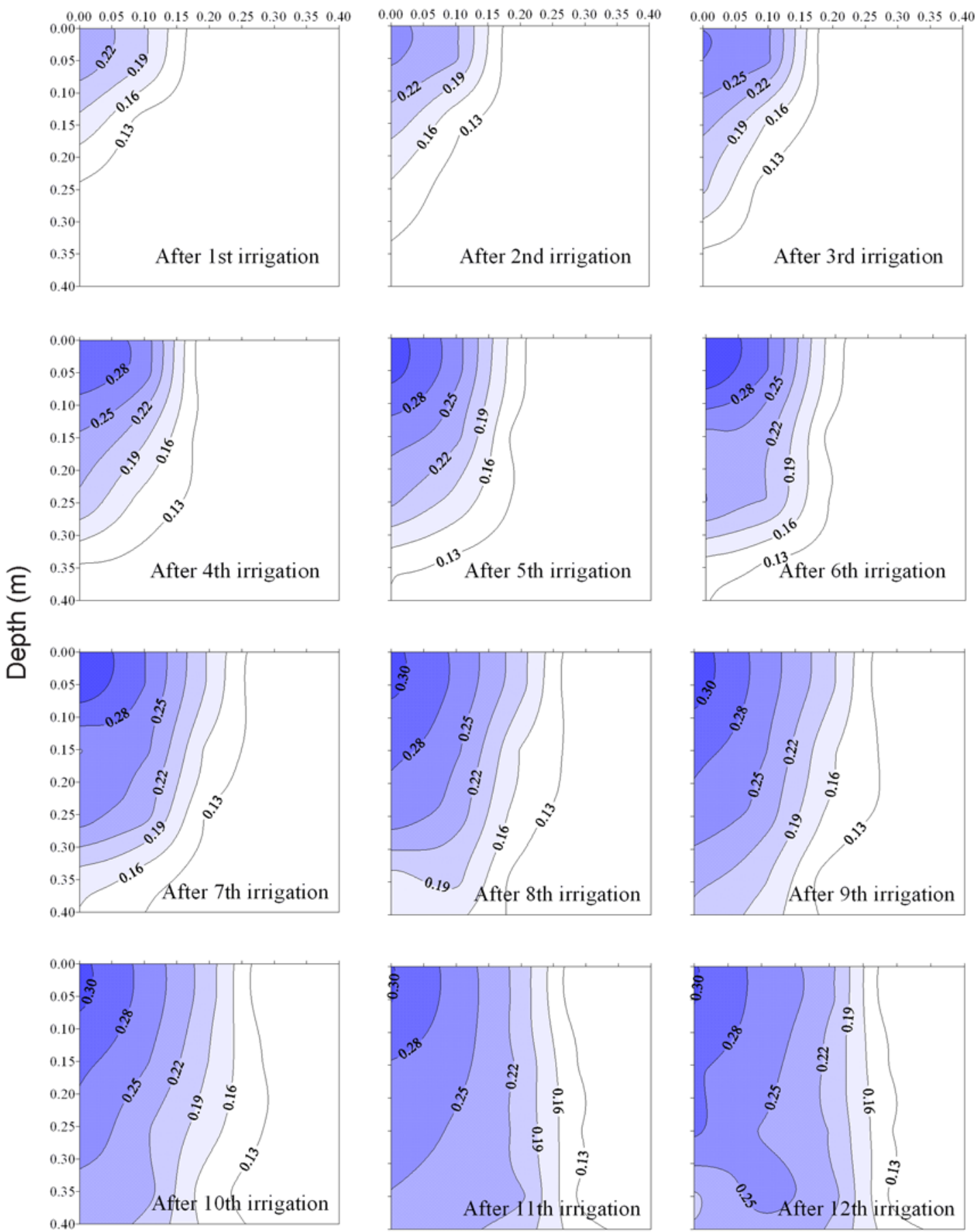

Figure 3 - Soil water content profiles $\left(\mathrm{m}^{3} \mathrm{~m}^{-3}\right)$ at the end of the infiltration process of each application of solution at a flow rate of $4 \mathrm{~L} \mathrm{~h} \mathrm{~h}^{-1}$. 
air and soil temperatures and air relative humidity. However, the data did not reveal any direct influence on the parameters observed during the evolution of the formation of the wetted soil volume.

Figures 3 and 6 present, respectively, the moisture content and electrical conductivity profiles recorded during the first six applications of a $\mathrm{KNO}_{3}$ solution. This number of applications was chosen because the solution distribution profiles indicated that the wetting front reached the bottom of the container after seven applications, interfering in the dimensions of the wetted soil volume from that time on.

The storage of the solution in the soil profile under study was identified in this experiment (Table 2). During all the applications of the solution, the 0 to $0.10 \mathrm{~m}$ layer of soil stored the highest percentage of the solution, i.e., $53 \%$, while the 0.10 to $0.20 \mathrm{~m}$ layer stored $28 \%$. The solution flow into the third layer $(0.20$ to $0.30 \mathrm{~m})$

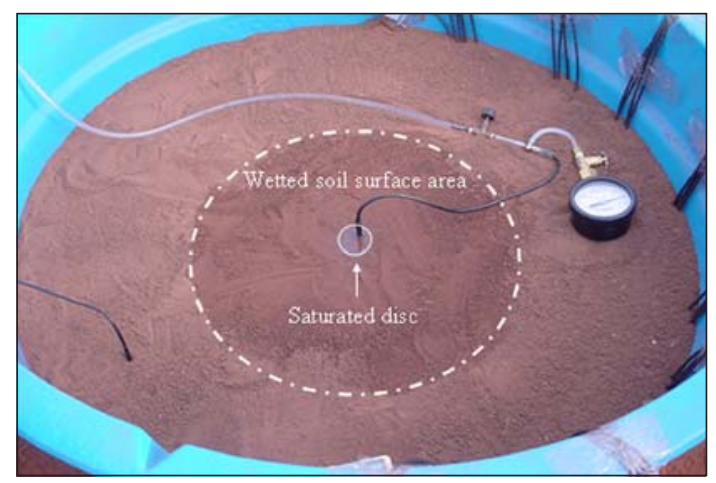

Figure 4 - Saturated disc and wetted soil surface area. was monitored only after the second application; this flow reached the last layer $(0.30$ to $0.40 \mathrm{~m})$ after the fourth application. There is a relation between the storage and the volume of water applied to the wetted soil volume, and increasing the volume causes the storage of water to move to the deepest layer of the soil profile.

Interactions among the profile water contents and concentration revealed a gradient distribution of the solution in the soil, with greater storage of solution close to the dripper, which gradually diminished as it approached the wetting front. However, an analysis of the mass distribution of potassium nitrate in relation to soil water content indicated a trend towards uniform concentration at all points, although a slight tendency was

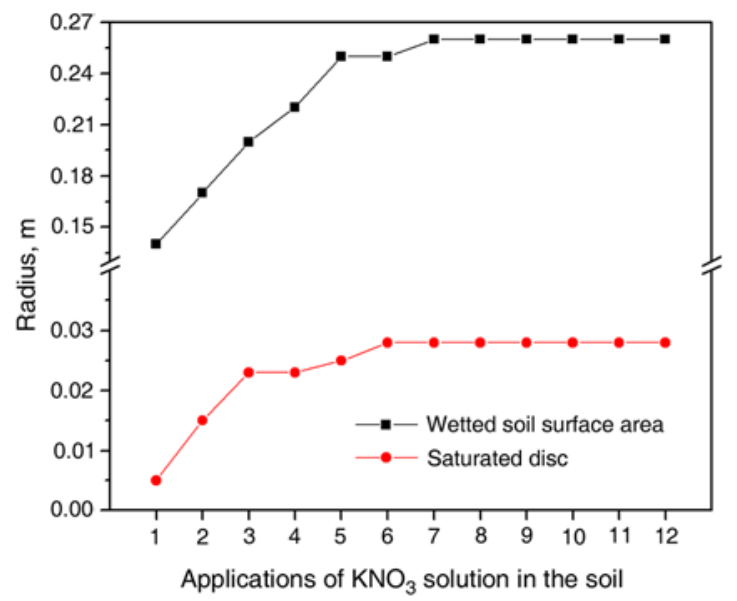

Figure 5 - Surface area of the wetted soil volume and saturated disc observed during the experiment after applications of solution.

\section{Distance from the dripper $(\mathrm{m})$}

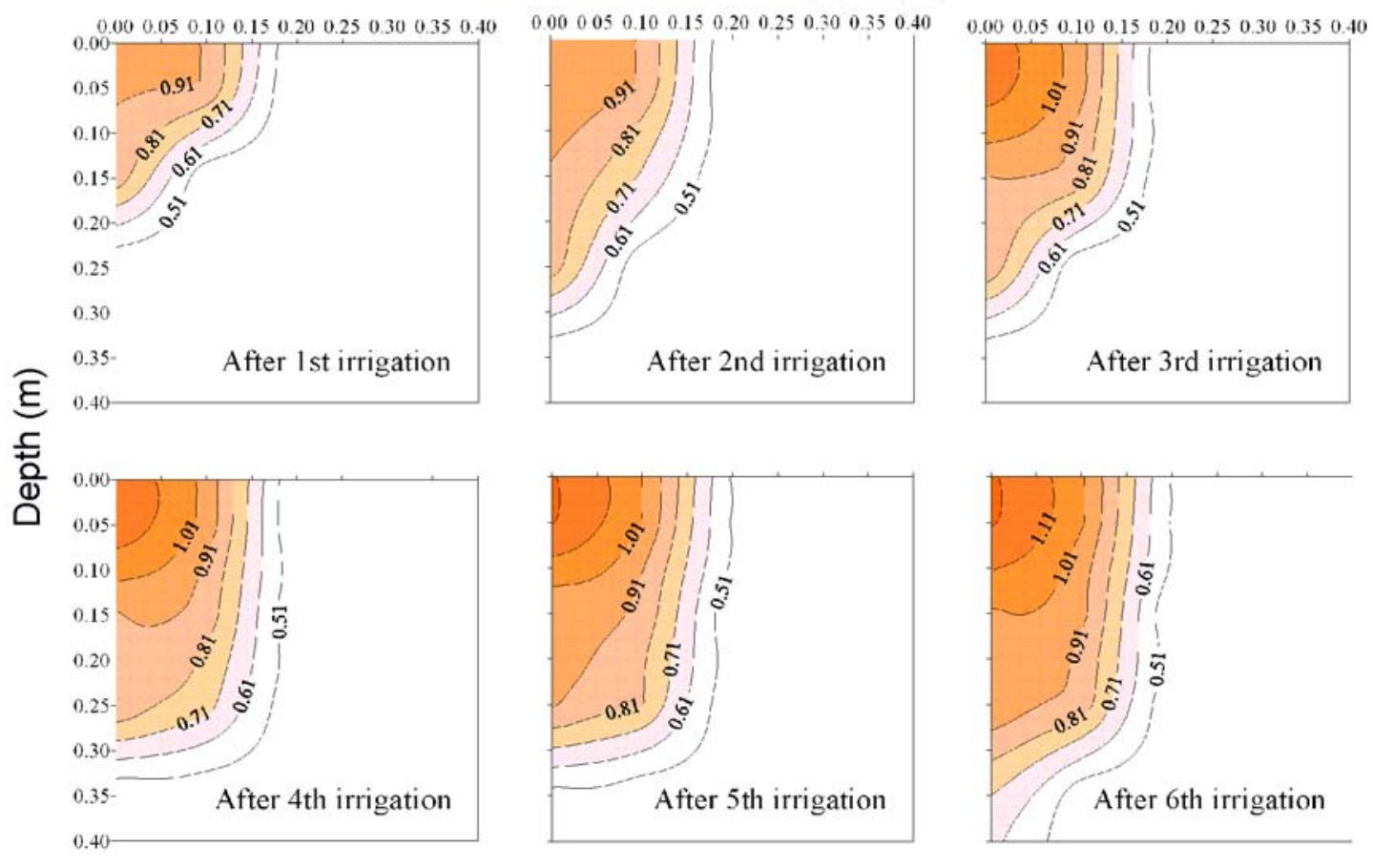

Figure 6 - Distribution of electrical conductivity in the soil $\left(\mathrm{dS} \mathrm{m}^{-1}\right)$. 
Table 2 - Estimated volume and concentration of solution for the soil distribution profile.

\begin{tabular}{|c|c|c|c|c|c|c|}
\hline \multirow{3}{*}{ Applications } & \multirow{3}{*}{ Total estimated solution } & \multirow{3}{*}{ Partial estimated solution } & \multicolumn{4}{|c|}{ Distribution of the solution in volume } \\
\hline & & & \multicolumn{4}{|c|}{ Layer $(\mathrm{m})$} \\
\hline & & & $0-0.1$ & $0.1-0.2$ & $0.2-0.3$ & $0.3-0.4$ \\
\hline \multicolumn{7}{|c|}{ Volume (L) } \\
\hline $1^{\text {st }}$ & 0.92 & 0.92 & 0.81 & 0.11 & 0 & 0 \\
\hline $2^{\text {nd }}$ & 1.83 & 0.91 & 0.53 & 0.23 & 0.15 & 0 \\
\hline $3^{\text {rd }}$ & 2.77 & 0.94 & 0.46 & 0.32 & 0.16 & 0 \\
\hline $4^{\text {th }}$ & 3.70 & 0.93 & 0.39 & 0.33 & 0.20 & 0.01 \\
\hline $5^{\text {th }}$ & 4.66 & 0.96 & 0.41 & 0.28 & 0.20 & 0.07 \\
\hline $6^{\text {th }}$ & 5.59 & 0.93 & 0.37 & 0.30 & 0.19 & 0.07 \\
\hline \multicolumn{7}{|c|}{ Concentration $\left(\mathrm{mmol} \mathrm{L}^{-1}\right)$} \\
\hline $1^{\text {st }}$ & 2.04 & 2.04 & 1.40 & 0.64 & 0 & 0 \\
\hline $2^{\text {nd }}$ & 3.03 & 0.99 & 0.32 & 0.32 & 0.35 & 0 \\
\hline $3^{\text {rd }}$ & 3.60 & 0.57 & 0.19 & 0.19 & 0.19 & 0 \\
\hline $4^{\text {th }}$ & 3.98 & 0.38 & 0.10 & 0.10 & 0.14 & 0.04 \\
\hline $5^{\text {th }}$ & 4.66 & 0.68 & 0.23 & 0.15 & 0.13 & 0.18 \\
\hline $6^{\text {th }}$ & 5.90 & 1.24 & 0.26 & 0.25 & 0.32 & 0.41 \\
\hline
\end{tabular}
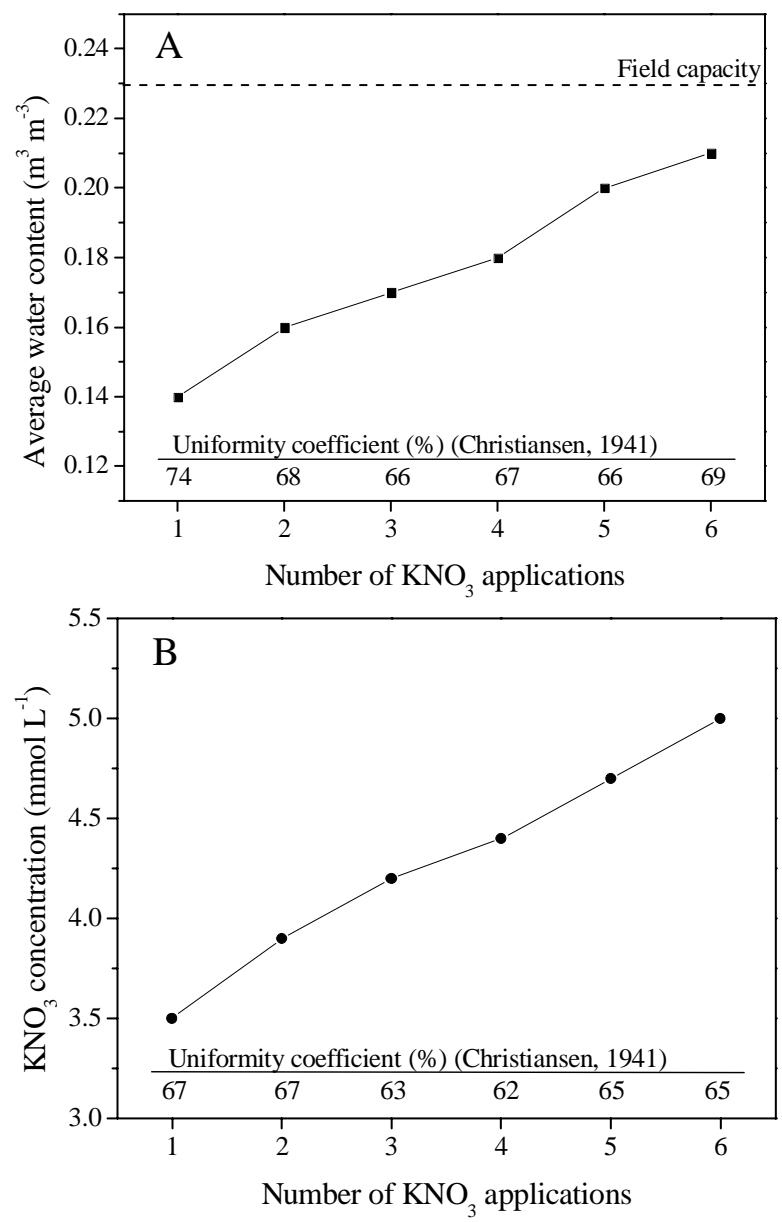

Figure 7 - (A) Average soil water content after the application of water to the control volume, and distribution homogeneity coefficient of the applied solution; (B) $\mathrm{KNO}_{3}$ concentration. found for this concentration to decrease in the soil close to the dripper after the fourth application as a result of $\mathrm{KNO}_{3}$ flowing towards the edge of the wetted soil volume and the continuous increase in moisture at this site.

The solute front is retarded relative to the wetting front (Blanco and Folegatti, 2001, 2002). However, the modification of this initial condition resulting from the distribution of ions in the profile led to a second condition, in which the electrical conductivity of the newly applied solution and that of the solution adjacent to the dripper showed similar values, promoting the movement of the ions towards the edges of the soil container, accompanying the water flow, in search of the aforementioned stability. Another observation is based on the soil CEC (Cation Exchange Capacity) (Rivera, 2004), i.e., the potassium of the solution in the soil interacted with the content of cations. This element was therefore retained in the soil adjacent to the point of application, and the solution that flowed to the furthermost regions of the wetted soil volume showed a lower ion concentration.

It is suggested that the distribution of ion concentrations should be studied in a larger number of successive events. This would allow for a better understanding of the phenomenon that occurred during the dynamics of the solution in the soil, providing objective information to help the farmer make the best fertigation management decisions.

\section{Analysis of the homogeneity of solution distributed in the soil}

Figure 7 presents an evaluation of the average soil water content in the control volume, shedding light on some of the problems caused by the homogeneity of the distribution of the solution in the soil. The field capac- 
ity was not reached at any moment during the applications of the solution, but the average moisture content approached the field capacity after the sixth application. In the control volume, stabilization of the average soil water content did not occur, demonstrating that the distribution of water in the soil depended on the applied volume. Punctual soil water contents of up to $0.34 \mathrm{~m}^{3} \mathrm{~m}^{-3}$ were observed in the experiment in which $6 \mathrm{~L}$ of solution were used.

The highest CUC was observed after the first application, although the values varied little from the average CUC of $68 \%$. Thus, it can be inferred that the application of different amounts of solution in the soil does not affect the CUC value.

The values of the distribution homogeneity coefficient for the potassium nitrate distribution profiles were congruous with those observed for the distribution of water in the soil. This confirmed the strong mobility of potassium nitrate in the soil, which accompanied the water flow in the soil, forming a gradient towards the edge of the wetted soil volume.

This finding reinforces the importance of being able to change the distribution of solution in the soil through different combinations of spacing between drippers. Solution that is more evenly distributed in the soil, raising the CUC above the values observed here, spreads the fertilizer homogeneously to the plant root system, reducing the loss of ions through leaching and contributing to transport nutrients to the roots through mass flow and diffusion mechanisms. Again, economic considerations are indispensable in view of investments in the project with increasing numbers of drippers, confirming the relevance of studying different dripper discharge rates and spacing combinations.

\section{Conclusions}

- With proper calibration, the TDR and methodology presented here are very promising in the study of the dynamics of solution in the soil.

- Under laboratory conditions, a direct correlation was found between the evolution of the saturated radius and the surface area of wetted soil.

- The interactions between the profiles (soil water content versus electrical conductivity) revealed a gradient distribution of the solution in the soil, with greater storage of solution adjacent to the dripper, gradually decreasing as it approached the wetting front.

- Based on the volume and frequency used during this experiment, it is recommended to reduce the leaching of ions that the application is made of small amounts of solution at more frequent intervals.

\section{Acknowledgement}

To FAPESP (Fundação de Amparo à Pesquisa do Estado de São Paulo) (Protocols \# 03/00067-6 and \# 05/ 00906-3).

\section{References}

Blanco, F.F.; Folegatti, M.V. 2001. Recuperação de um solo salinizado após cultivo em ambiente protegido. Revista Brasileira de Engenharia Agrícola e Ambiental 5: 76-80.

Blanco, F.F.; Folegatti, M.V. 2002. Salt accumulation and distribution in a greenhouse soil as affected by salinity of irrigation water and leaching management. Revista Brasileira de Engenharia Agrícola e Ambiental 6: 414-419.

Bresler, E. 1978. Analysis of trickle irrigation with application to design problem. Irrigation Science 1: 3-17.

Christiansen, J.E. 1941. The uniformity of application of water by sprinkler systems. Agricultural Engineering 22: 89-92.

Coelho, E.F.; Or, D. 1996. Flow and uptake patterns affecting soil water sensor placement for drip irrigation management. Transactions of the ASAE 39: 2007-2016.

Coelho, E.F.; Or, D. 1999. Root distribution and water uptake patterns of corn under surface and subsurface drip irrigation. Plant and Soil 206: 123-136.

Dasberg, S.; Or, D. 1999. Drip Irrigation. Springer, Berlin, Germany.

Keller, J.; Bliesner, R. 1990. Sprinkle and Trickle Irrigation. Chapman and Hall, New York, NY, USA.

Mmolawa, K.; Or, D. 2000. Root zone solute dynamics under drip irrigation: A review. Plant and Soil 222: 163-190.

Ould Mohamed El-Hafedh, A.V.; Daghari, H.; Maalej, M. 2001. Analysis of several discharge rate-spacing-duration combinations in drip irrigation system. Agricultural Water Management 52: 33-52.

Rhoades, J.D.; Raats, P.A.; Prather, R.J. 1976. Effects of liquid phase electrical conductivity, water content and surface conductivity on bulk soil electrical conductivity. Soil Science Society of America Journal 40: 651-655.

Rivera, R.N.C. 2004. Modelagem da dinâmica da água e do potássio na irrigação por gotejamento superficial. Dr. Thesis. Universidade de São Paulo, Piracicaba, SP, Brazil. (in Portuguese with summary in English).

Souza, C.F.; Matsura, E.E. 2003. Determination of the wetting front in drip irrigation using TDR Multi-wire probe. Agricultural Water Management 59: 205-216.

Souza, C.F.; Matsura, E.E. 2004. Distribuição da água no solo para o dimensionamento da irrigação por gotejamento. Revista Brasileira de Engenharia Agrícola e Ambiental 8: 7-15.

Souza, C.F.; Folegatti, M.V.; Matsura, E.E.; Or, D. 2006a. Calibração da Reflectometria no Domínio do Tempo (TDR) para a estimativa da concentração da solução no solo. Revista Engenharia Agrícola 26: 282-291.

Souza, C.F.; Folegatti, M.V.; Matsura, E.E.; Or, D; Coelho, E.F. 2006b. Sondas de TDR para a estimativa da umidade e da condutividade elétrica do solo. Revista Irriga 11: 12-25.

Topp, G.C.; Davis, J.L.; Annan, A.P. 1980. Electromagnetic determination of soil water content: measurements in coaxial transmission lines. Water Resource Research 16: 574-582.

Vieira, D.B.; Francisco, J.AG. 1986. Formação do bulbo molhado sob gotejamento em Latossolo vermelho amarelo - orto. In: Proceedings do Congresso Nacional de Irrigação e Drenagem 7. Associação Brasileira de Irrigação e Drenagem [ABIRD], Brasília, DF, Brazil.

Wiens, P.E.; Souza, C.F.; Matsura, E.E.; Queiroz, S.O.P. 2002. Avaliação da técnica da TDR (Reflectometria no Domínio do Tempo) no estudo da dinâmica de solutos no solo. In: Proceedings do Congresso Brasileiro de Engenharia Agrícola 31. Sociedade Brasileira de Engenharia Agrícola [SBEA]/UFBA, Salvador, BA, Brazil (CD ROM, unnumbered pages).

WINTDR. Time Domain Reflectometry soil sample analysis program. Available at: http://soilphysics.usu.edu/wintdr [Accessed May 15, 2004]

Wu, I.P.; Gitlin, H.M. 1983. Drip irrigation application efficiency and schedules. Transactions of the ASAE 26: 92-99.

Received October 24, 2007

Accepted August 04, 2009 